\title{
Ganglioneuroma Component Present
}

National Cancer Institute

\section{Source}

National Cancer Institute. Ganglioneuroma Component Present. NCI Thesaurus. Code C42068.

A finding indicating the presence of large gang lion cells, neural cellular infiltrates and a stroma with Schwannian differentiation in a neoplastic tissue specimen. 